\title{
Signifikansi YouTube Sebagai Medium Pewartaan Injil Bagi Generasi Milenial di Indonesia
}

\author{
David Eko Setiawan \\ Sekolah Tinggi Teologi Tawangmangu \\ davidekosetiawan14217@gmail.com \\ D0I: https://doi.org/10.34307/b.v4i2.190
}

\begin{abstract}
The rapid development of informatics technology gave rise to various social media platforms that can connect many people from all walks of life, and everywhere quickly. In various studies showed that the most users of the platform there are millennials. Freedom and speed to access it, have become a driving factor for the use of social media as a medium of preaching the Gospel. As one type of social media that is favored by millennials, YouTube can help gospel reporters to communicate more attractively, creatively, interactively, and inspiringly. The problem of this research is how is the significance of YouTube as a medium of preaching the Gospel for millennials in Indonesia? Researchers used two methods to solve the problem in the study: the library research method and the survey. This research aims to explain the significance of YouTube as a medium of preaching the Gospel for millennials in Indonesia. In this study, it was found that YouTube is basically significant as a medium of preaching the gospel for millennials in Indonesia because it suits the context of those who love attractive, creative, interactive, and inspiring social media platforms.
\end{abstract}

Keywords: Significance, YouTube, Medium, Gospel Preaching, Millennial Generation

\begin{abstract}
Abstrak: Perkembangan teknologi informatika yang begitu cepat memunculkan berbagai platform media sosial yang dapat menghubungkan banyak orang dari segala lapisan, dan di segala tempat secara cepat. Dalam berbagai penelitian menunjukkan bahwa pengguna terbanyak dari platform tersebut ada generasi milenial. Kebebasan dan kecepatan untuk mengaksesnya, telah menjadi faktor pendorong bagi pemanfaatan media sosial sebagai medium pewartaan Injil. Sebagai salah satu jenis media sosial yang disukai oleh generasi milenial, YouTube dapat menolong pewarta injil untuk berkomunikasi secara lebih atraktif, kreatif, interaktif dan inspiratif. Masalah penelitian ini adalah bagaimana signifikansi YouTube sebagai medium pewartaan Injil bagi generasi milenial di Indonesia? Peneliti menggunakan dua metode untuk memecahkan masalah dalam penelitian ini, yaitu metode library research dan survei. Penelitian ini bertujuan menjelaskan signifikansi YouTube sebagai medium pewartaan Injil bagi generasi milenial di Indonesia. Pada penelitian ini ditemukan bahwa pada dasarnya YouTube signifikan sebagai medium pewartaan Injil bagi generasi milenial di Indonesia karena sesuai dengan konteks mereka yang menggemari platform media sosial yang atraktif, kreatif, interaktif dan inspiratif.
\end{abstract}

Kata Kunci: Signifikansi, YouTube, Medium, Pewartaan Injil, Generasi Milenial

\begin{tabular}{llll}
\hline Article History : & Received: 11-07-2020 & Revised: 21-06-2021 & Accepted: 26-06-2021
\end{tabular}




\section{Pendahuluan}

Injil harus diwartakan sampai ke seluruh bumi (Kis. 1:8). Namun demikian perlu metode yang tepat agar berita Injil dapat didengar dan direspon oleh banyak orang. Perubahan dunia yang sangat cepat menuntut adanya inovasi dalam mengkomunikasikan pesan Injil. Gereja seyogyanya mulai menyesuaikan terhadap perubahan tersebut. ${ }^{1}$ Disamping itu, peningkatan populasi penduduk berkategori milenial juga harus menjadi perhatian khusus bagi gereja, khususnya di Indonesia. Pada tahun 2020, Badan Pusat Statistik Nasional mencatat bahwa jumlah penduduk yang tergolong dalam kelompok milenial mencapai 25,87\% dari jumlah keseluruhan penduduk Indonesia. ${ }^{2}$ Jumlah tersebut memberikan sumbangsih terhadap struktur penduduk usia produktif yang jumlah totalnya adalah $70,72 \%$, yang artinya bahwa salah satu kelompok usia produktif terbesar di Indonesia merupakan generasi milenial. ${ }^{3}$ Penelitian menunjukkan bahwa selain mereka merupakan salah satu generasi usia produktif terbesar, mereka juga merupakan kelompok usia yang sangat dekat dengan smartphone ${ }^{4}$ dan media sosial. ${ }^{5}$ Mereka menggunakan sepertiga hari untuk mengakses media sosial dengan alokasi waktu 11 jam 26 per hari. ${ }^{6}$ Mengutip data dari Asosiasi Penyelenggara Jasa Internet Indonesia (APJII), Nofitasari menyatakan bahwa generasi milenial (usia 10-34 tahun) adalah pengguna internet terbanyak di Indonesia. ${ }^{7}$ Generasi ini sangat tergantung dengan internet, smartphone dan berbagai jenis media sosial.

YouTube adalah media sosial yang sangat disukai oleh penduduk di Indonesia. Merujuk pada hasil laporan Hootsuite dalam Indonesian Digital Report 2019 menunjukkan bahwa YouTube telah menjadi media sosial yang paling disukai masyarakat Indonesia (88\%). ${ }^{8}$ Dalam jajak pendapat yang dilakukan oleh peneliti kepada 55 responden warga gereja di wilayah Jawa Tengah ditemukan bahwa 98, 2\% menyatakan bahwa mereka aktif mengakses YouTube. 81, 5\% menyatakan bahwa mereka mengakses YouTube sebanyak 10 kali dalam sehari. Dan sebanyak 52,7\% dari mereka adalah generasi Milenial. Datadata tersebut memperjelas fakta bahwa YouTube merupakan platform media sosial yang sangat dekat dan digemari oleh generasi milenial di Indonesia.

${ }^{1}$ Ezra Tari, “Teologi Tongkonan : Berteologi Dalam Konteks Budaya Toraja” 2, no. 2 (2018): 94.

2 [BPS] Badan Pusat Statistik, Berita Resmi Statistik, Bps.Go.Id, 2020, 4.

${ }^{3}$ Ibid., 1.

${ }^{4}$ Poppy Panjaitan, "Pengaruh Sosial Media Terhadap Produktivitas Kerja Generasi MilleniaL (Studi Pada Karyawan PT . Angkasa Pura I Cabang Bandara Internasional Juanda )," Jurnal Administrasi Bisnis (JAB) 48, no. 1 (2017): 174.

${ }^{5}$ Apriani M. Sibarani, "Media Sosial Sebagai Konteks Pendidikan Kristiani Kontekstual Bagi Generasi Millennial," Jurnal Ilmiah Maksitek 5, no. 2 (2020): 13.

${ }^{6}$ Ibid.

${ }^{7}$ Nofitasari, "Pengaruh Media Sosial Terhadap Civic Disposition Generasi Milenial," Journal of Moral and Civic Education 2, no. 2 (2018): 65.

${ }^{8}$ We Are Social \& Hootsuite, Indonesia Digital Report 2020, Global Digital Insights, 2020, 33, https://datareportal.com/reports/digital-2020-global-digital-overview. 
Penelitian yang berusaha menggali keterkaitan media sosial dengan generasi milenial telah dilakukan oleh beberapa peneliti sebelumnya. Sibarani dalam penelitiannya menemukan bahwa media sosial dapat menjadi peluang bagi pendekatan Shared Christian Praxis dalam pendidikan Kristen kontekstual. Penelitian ini berfokus untuk menemukan pendekatan bagi pendidikan Kristen kontekstual melalui media sosial bagi masyarakat Kristen virtual. ${ }^{9}$ Rupanya, topik penelitian ini terkait dengan masalah yang sedang diteliti oleh penulis, namun ada perbedaannya yaitu pada fokus penelitiannya, dimana peneliti lebih memfokuskan pada platform media sosial YouTube. Selain itu peneliti juga memiliki objek yang berbeda yaitu generasi milenial di Indonesia yang perlu mendengar pesan Injil. Penelitian lain yang relevan adalah penelitian Passa yang berusaha menunjukkan bahwa media internet dapat dimanfaatkan bagi media pemberitaan Injil (P.I) bagi seluruh umat manusia di segala penjuru dunia. Melalui penelitiannya, ditemukan bahwa terdapat fitur-fitur di media internet yang dapat menjadi alat P.I semisal; E-Mail, Web, Blog, Facebook, Chat Rooms, Mailing List, News Group, FTP, Inter Relay Chat, Teleconference. ${ }^{10}$ Rupanya berbagai fitur tersebut merupakan pilihan terbaik sebagai medium pewartaan injil pada tahun 2015, namun semenjak tahun 2020 tren pengguna media sosial telah bergeser kepada platform yang lain yaitu YouTube. Hal tersebut tampak dari laporan Hootsuite dalam Indonesian Digital Report 2021 yang menyatakan bahwa platform media sosial yang paling digemari oleh kalangan usia 16-64 tahun adalah YouTube, yaitu sebesar 93,8\%.11 Berdasarkan laporan tersebut, tampak peningkatan yang signifikan pada penggunaan platform YouTube dibandingkan tahun 2019 yaitu sebesar 88\%. ${ }^{12}$ Jika dilihat dari data usia pengakses YouTube di atas tampak bahwa generasi Milenial merupakan salah satu kelompok usia terbesar pengguna platform tersebut. Hal inilah yang kemudian mendorong peneliti untuk memfokuskan penelitiannya pada YouTube sebagai medium pewartaan Injil bagi generasi Milenial dibandingkan dengan jenis media sosial lainnya.

Masalah dalam riset ini ialah bagaimanakah signifikansi YouTube sebagai medium pewartaan Injil bagi generasi milenial di Indonesia? Adapun tujuan riset ini ialah untuk menjelaskan signifikansi YouTube sebagai medium pewartaan Injil bagi generasi milenial di Indonesia.

\section{Metode Penelitian}

Penelitian ini berjenis deskriptif kualitatif, dimana peneliti secara detail menggambarkan perihal masalah atau perkara tertentu dalam bentuk narasi. ${ }^{13}$ Teknik pengumpulan data

${ }^{9}$ Sibarani, "Media Sosial Sebagai Konteks Pendidikan Kristiani Kontekstual Bagi Generasi Millennial," 13-18.

${ }^{10}$ Adrianus Pasasa, "Pemanfaatan Media Internet Sebagai Media Pemberitaan Injil," Jurnal Simpson II (2015): 71-98.

${ }^{11}$ We Are Social \& Hootsuite, “Digital Data Overview 2021: Indonesia," Global Digital Insights, 47.

${ }^{12}$ We Are Social \& Hootsuite, Indonesia Digital Report 2020, 33.

${ }^{13}$ Bagong Suyanto, Metode Penelitian Sosial: Berbagai Alternatif Pendekatan (Jakarta, 2015), xiv. 
pada penelitian ini memakai metode library research dan survei. Data-data yang terkait dengan bahan-bahan kepustakaan yang berasal dari buku-buku dan jurnal-jurnal ilmiah, dikumpulkan, ditelaah dan disaring menggunakan metode library research, dan selanjutnya disusun menjadi kerangka pemikiran teoritis. ${ }^{14}$ Dengan metode survei, peneliti mengumpulkan data-data primer melalui pertanyaan-pertanyaan berstandar yang diajukan kepada para responden. ${ }^{15}$ Mereka semua mendapatkan jenis pertanyaan yang sama dan tidak ada peluang untuk mengajukan pertanyaan susulan. ${ }^{16}$

Data-data yang diperoleh melalui metode library research dianalisis menggunakan analisis isi (content Analysis) dimana di dalam analisis ini peneliti berusaha untuk menafsirkan bahan-bahan yang bersumber dari berbagai kepustakaan untuk mendapatkan gambaran yang jelas atas masalah yang sedang diteliti. Untuk datadata yang diperoleh melalui metode survei, peneliti menganalisanya menggunakan analisis deskriptif. Analisis ini menitikberatkan pada penggambaran atas data yang telah diperoleh dari para responden.

\section{Hasil dan Pembahasan}

\section{Media Sosial: Sebuah Medium Interaksi Online}

Perkembangan yang sangat cepat dibidang teknologi informasi, rupanya telah menciptakan pergeseran dalam mencari berbagai informasi. Saat ini masyarakat cenderung untuk mencari informasi dengan cara online ketimbang konvensional. Ini didasarkan pertimbangan kecepatan akses yang didapatkannya. Kecenderungan tersebut rupanya telah menjadi salah satu faktor pendorong bagi perkembangan media online, yang salah satunya adalah media sosial. Media ini tampaknya telah berkontribusi cukup besar dalam menciptakan interaksi sosial di dunia maya.

Media sosial dapat diartikan sebagai alat online yang memudahkan penggunanya untuk bergabung, berbagi, dan membuat konten seperti blog, jejaring sosial, wiki, forum dan dunia virtual." ${ }^{17}$ Selanjutnya, media sosial juga dapat dimengerti sebagai media online berbasis web yang mendukung relasi aktif antar individu dalam suatu komunikasi yang lebih interaktif." ${ }^{18}$ Berdasarkan beberapa pengertian tersebut maka media sosial dapat

${ }^{14}$ Kartini Kartono, Pengantar Metodologi Research Sosial (Bandung: Alumni Bandung, 1980), 78.

${ }^{15}$ M. A. Morrisan, Metode Penelitian Survei (Jakarta, 2012), 26.

16 Ibid.

17 Anang Sugeng Cahyono, "Pengaruh Media Sosial Terhadap Perubahan Sosial Masyarakat Di Indonesia," Jurnal ilmu sosial \& ilmu politik diterbitkan oleh Fakultas Ilmu Sosial \& Politik, Universitas Tulungagung 9, no. 1 (2016): 142, http://www.jurnal-unita.org/index.php/publiciana/article/download/ $79 / 73$.

${ }^{18}$ Panjaitan, "Pengaruh Sosial Media Terhadap Produktivitas Kerja Generasi Millenial ( Studi Pada Karyawan PT . Angkasa Pura I Cabang Bandara Internasional Juanda ),” 174. 
dikatakan sebagai medium interaksi sosial yang berbasis online ${ }^{19}$ dimana para penggunanya dapat menciptakan konten, berdialog dan berbagi sesuatu di dalamnya.

\section{Mengenal Berbagai Varian Media Sosial}

Media sosial sebagai medium interaksi sosial yang berbasis online memiliki beberapa varian. Kaplan dan Haenlein menjelaskan beberapa varian tersebut sebagai berikut: ${ }^{20}$ Pertama, Proyek-proyek Kolaborasi. Varian media sosial ini memungkinkan para penggunanya untuk membuat konten secara bersama dan diakses secara global. Konten tersebut dapat ditambah, diubah, dan dihapus oleh penggunanya. Varian ini diwakili oleh Wiki. Sedangkan Social Bookmark Applications merupakan bagian dari varian ini yang dapat digunakan untuk membentuk grup serta menyusun peringkat tautan internet atau muatan media. Model dari varian ini misalnya Delicious, Technorati, Lintas Berita.

Kedua, Blog. Blog adalah jenis media sosial yang berbentuk website pribadi, yang di dalamnya dapat berbentuk tulisan, gambar bergerak, foto dan tautan ke website lain, yang dimiliki blogger dan berisi sekumpulan konten. Blog biasanya dijalankan oleh hanya satu orang saja namun di dalamnya dihadirkan juga ruang untuk dapat terhubung dengan orang lain melalui kolom komentar yang telah disediakan. Sedangkan contoh varian tersebut misalnya; Blogspot, LiveJournal, Blogsome.

Ketiga, Content Communities. Varian media sosial ini diciptakan untuk berbagi konten media antara pengguna. Pengguna dapat menjumpai beberapa bentuk media dalam varian ini antara lain teks, foto, video, presentasi Powerpoint. Pengguna Content Communities tidak diwajibkan membuat halaman profil pribadi; Dalam hal ini, halaman hanya terdiri dari keterangan tentang waktu penggabungan pada komunitas serta jumlah video yang telah diposting. Model varian ini antara lain YouTube, BookCrossing, Flickr, Slideshare.

Keempat, Situs Jejaring Sosial. Jenis ini memungkinkan para penggunanya dapat saling terkoneksi dan mencantumkan profil informasi pribadi serta memberikan akses kepada rekan yang diundang agar dapat membuka profil tersebut, dan dapat saling bertukar email dan pesan instan. Isi yang termuat di dalam profil pribadi tersebut antara lain berbagai jenis keterangan berupa gambar, video, suara, dan blog. Contoh untuk varian ini adalah Facebook, Instagram

Kelima, Dunia Game Virtual. Varian ini menampilkan lingkungan tiga dimensi yang memungkinkan penggunanya untuk muncul dalam bentuk avatar yang dipersonalisasi dan mampu berinteraksi satu sama lain seperti dalam kehidupan nyata. Di sini, pengguna dapat terlibat dalam game yang melibatkan banyak pemain dan berinteraksi sesuai

\footnotetext{
${ }^{19}$ Ike Atikah Ratnamulyani dan Beddy Iriawan Maksudi, "Peran Media Sosial Dalam Peningkatan Partisipasi Pemilih Pemula Dikalangan Pelajar Di Kabupaten Bogor" 20, no. 2 (2018): 156.

${ }^{20}$ Andreas M. Kaplan and Michael Haenlein, "Users of the World, Unite! The Challenges and Opportunities of Social Media," Business Horizons 53, no. 1 (2010): 62-64.
} 
dengan aturan game yang ada. Contoh dari varian ini semisal PUBG Mobile, Mobile Legends, game online lainnya.

Keenam, Dunia sosial Virtual. Varian ini memungkinkan penggunanya untuk hidup di dalam dunia virtual yang tidak dibatasi oleh apapun. Pengguna dapat berinteraksi dengan menggunakan avatar yang telah dipersonalisasikan di dalam dunia virtual tersebut. Contoh varian ini adalah second life.

\section{Fungsi Media Sosial}

Terdapat berbagai fungsi yang berbeda dari media sosial antara lain sebagai lain: ${ }^{21}$ Pertama, untuk mengembangkan jejaring sosial melalui teknologi internet. Fungsi ini telah membuat media sosial memiliki kekuatan untuk membangun jejaring didalam masyarakat dari segala lapisan tanpa dibatasi oleh apapun.

Kedua, mentransformasi budaya komunikasi media. Transformasi tersebut tampak dari perubahan praktik komunikasi yang terjadi dalam satu lembaga media dengan khalayak yang besar (one to many) menjadi praktik komunikasi interaktif yang melibatkan banyak khalayak (many to many).

Ketiga, dapat mendorong terciptanya kebebasan mengakses konten pengetahuan dan informasi. Fungsi ini telah mentransformasi masyarakat dari hanya sekedar penerima konten menjadi pembuat konten.

\section{YouTube : Platform Media Sosial berbasis Berbagi Video}

YouTube adalah platform social media yang disukai oleh masyarakat. Rupanya YouTube telah digunakan oleh satu milyar penduduk di seluruh dunia, artinya sepertiga dari seluruh pengguna internet merupakan pengguna YouTube. ${ }^{22}$ Sebagian besar penggunanya berada pada rentang usia 18-34 tahun, dan lebih dari 70\% pengaksesnya menggunakan perangkat seluler. ${ }^{23}$ Bagaimanakah dengan masyarakat Indonesia? Menurut survei yang dilakukan oleh Google atas nama YouTube, 92\% pengguna internet di Indonesia menempatkan YouTube sebagai tujuan pertama pencarian video favorit mereka. ${ }^{24}$

Apakah sesungguhnya YouTube itu? YouTube merupakan situs web berbasis video sharing yang penggunanya dapat, mengupload, menikmati serta mengomentari video tersebut. Bahkan para penggunanya dapat mengunduh video favoritnya serta menyimpannya. Platform ini memuat berbagai jenis video, mulai dari klip film, video musik, video blog, video tutorial dan lain-lain. Adapun karakteristik YouTube adalah

$$
16 .
$$

${ }^{21}$ Fahlepi Roma Doni, “Perilaku Penggunaan Media Sosial Pada Kalangan Remaja” 3, no. 2 (2017):

\footnotetext{
${ }^{22}$ Erik Fahron Setiadi, Alia Azmi, and Junaidi Indrawadi, "Youtube Sebagai Sumber Belajar Generasi Milenial," Journal of Civic Education 2, no. 4 (2019): 314.

${ }^{23}$ Ibid.

24 Ibid.
} 
sebagai berikut: ${ }^{25}$ Pertama, tidak membatasi durasi video yang diunggah. Pengguna YouTube dapat mengunggah videonya tanpa dibatasi oleh durasi. Kedua, memiliki sistem konfirmasi yang akurat untuk pengamanan. YouTube telah memperbaiki sistem keamanannya melalui metode konfirmasi sehingga video sebelum diunggah akan mendapatkan beberapa pertanyaan pengaman. Hal ini untuk menghindari konten video kekerasan, SARA, dll. Ketiga, berbayar. YouTube telah memberikan penawaran honorarium bagi pembuat video yang memperoleh 1000 viewer. Keempat, penyediaan sistem off line. YouTube telah menyediakan sistem menonton video dengan secara offline, pengguna dapat mengunduh video tersebut lebih dahulu, dan nantinya dapat dinikmati secara offline. Kelima, tersedia editor sederhana. Pengguna YouTube difasilitasi editor video secara sederhana, sehingga sebelum video diunggah maka dapat lebih dahulu di filter warna, dipotong atau menambah efek perpindahan video.

Selain karakteristik di atas, YouTube sebagai media online yang dapat dinikmati oleh sebagian besar masyarakat dunia, memiliki fungsi sebagai berikut: ${ }^{26}$ Pertama, manfaat sosial. Manfaat sosial ini berbentuk pemberian informasi, hiburan atau memberitakan sesuatu kepada massa atau khalayak melalui konten video yang diunggah. Disamping itu juga dapat memicu kreatifitas dan produktifitas penggunanya. Juga dapat memberikan nilai ekonomi bagi para content creator yang berhasil memiliki lebih dari 1000 viewer karena akan mendapat honorarium. Kedua, interaksi sosial. Melalui YouTube pengguna secara online berpartisipasi dengan memberikan saran kepada video yang ditontonnya.

\section{Generasi Milenial dan YouTube}

Setiap generasi dapat dikategorikan berdasarkan tahun kelahiran, pola pikir, gaya hidup dan ciri khasnya. ${ }^{27}$ Mereka yang dilahirkan sebelum tahun 1946 disebut generasi Traditionalist, sedangkan mereka yang terlahir kisaran tahun 1946-1964 dikenal sebagai generasi Baby Boomer, kemudian mereka yang dilahirkan antara tahun 1965-1979 dinamai sebagai generasi X.28 Untuk generasi Milenial terbagi menjadi dua kelompok, yaitu generasi Y yang terlahir pada tahun 1984-1993 dan Milenial yang terlahir tahun 1994-2002. Mereka ini juga dapat dikategorikan generasi yang lahir pada tahun 1980 2000, yang sekarang telah mencapai usia 20-40 tahun. ${ }^{29}$

Generasi milenial memiliki karakteristik yang cukup menarik sehubungan dengan pola pikir dan gaya hidupnya. Karakteristik generasi milenial dapat digambarkan

25 . Fatty Faiqah, . Muh. Nadjib, . Andi Subhan Amir, "Youtube Sebagai Sarana Komunikasi Bagi Komunitas Makassarvidgram," Jurnal Komunikasi KAREBA 5, no. 2 (2016): 261.

${ }^{26}$ Damayanti, Media Sosial, Identitas, Transformasi, Dan Tantangannya (Malang, 2020), 32-33.

${ }^{27}$ Stimson Hutagalung and Rolyana Ferinia, "Menjelajahi Spiritualitas Milenial : Apakah Membaca Alkitab , Berdoa , Dan Menghormati Ibadah Di Gereja Menurun ?" 2, no. 2 (2020): 99.

${ }^{28}$ Davis Stillman dan Jonah Stillman, Generasi Z (Jakarta: Gramedia, 2019), 1.

${ }^{29}$ Dinar Apriyanto, Dinar Apriyanto (Bantul: Psikologi Corner, 2017), 44. 
berikut: $^{30}$ Pertama, sangat dekat dengan gawai. Generasi milenial hampir tidak dapat melepaskan gawainya saat beraktifitas. Ketertarikan pada dunia online yang begitu tinggi menjadikan generasi ini sangat dekat dengan gadget. Kedua, mendedikasikan momen berharganya melalui media sosial. Mereka akan berusaha mengabadikan momentmoment penting dengan berswafoto atau yang sering disebut selfie. Selain itu tidak segansegan mereka merekam dalam bentuk video dan mengunggah ke media sosial favoritnya. Ketiga, wajib memiliki akun social media. Sebagian besar milenial, paling sedikit mempunyai satu akun media sosial. Seperti Facebook, Twitter, YouTube, dll. Pratama menjelaskan enam (6) Karakteristik generasi milenial sebagai berikut: ${ }^{31}$ Pertama, mediavora (pelahap media). Kedua, multi-tasking. Ketiga, Hiper-Koneksi. Keempat, toleran. Kelima, real time. Keenam, interaktif. Semua karakteristik tersebut menjadikan generasi milenial menjadi unik di zamannya.

Sehubungan dengan media sosial, ternyata YouTube merupakan platform yang paling digemari di tahun 2021 oleh kelompok usia 16-64 tahun. ${ }^{32}$ Jumlah pengguna dalam kelompok usia tersebut sebanyak 93,8\%, dan salah satu mayoritas pengaksesnya adalah generasi milenial. ${ }^{33}$ Peneliti juga telah mengadakan survei kepada 55 warga gereja di Jawa Tengah sehubungan kedekatan mereka dengan media sosial. 98, 2\% menyatakan bahwa mereka aktif mengakses YouTube. 81, 5\% menyatakan bahwa mereka mengakses YouTube sebanyak 10 kali dalam sehari. Dan sebanyak 52,7\% dari mereka adalah generasi milenial. Data-data ini membuktikan bahwa generasi milenial Nusantara memiliki kedekatan dengan YouTube. Mengapa demikian? Berdasarkan hasil survei penulis, 80\% generasi milenial menyatakan bahwa YouTube merupakan platform media sosial yang atraktif, kreatif, interaktif dan inspiratif. Ciri khas YouTube itulah yang menjadi daya tarik tersendiri bagi generasi milenial.

\section{Pewartaan Injil, Generasi Milenial Indonesia, dan YouTube}

Pewartaan Injil perlu dilakukan dengan berbagai metode, mengingat pesan Injil selalu hadir dalam berbagai konteks kehidupan manusia. Dalam kaitannya dengan generasi milenial, pewarta Injil seyogyanya mempertimbangkan metode yang tepat dalam mengkomunikasikan pesan tersebut kepada mereka. Jumlah populasi generasi milenial di Indonesia yang mencapai $33,7 \%$ tidak bisa dianggap sepele. ${ }^{34}$ Jumlah tersebut memberikan sumbangsih terhadap struktur penduduk usia produktif sebesar $50,36 \%$, yang artinya bahwa usia produktif penduduk Indonesia terbesar adalah generasi

\footnotetext{
${ }^{30}$ Faiza, “Mengenal Generasi Milenial," dalam Arus Metamorfosa Milenial (Kendal: Penerbit Ernest, 2018), 1-183.

${ }^{31}$ Hellen Chou Pratama, Cyber Smart Parenting: Kiat Sukses Menghadapi Dan Mengasuh Generasi Digital (Bandung, 2012), 35.

${ }^{32}$ We Are Social \& Hootsuite, "Digital Data Overview 2021: Indonesia," 47.

${ }^{33}$ Ibid.

${ }^{34}$ Indah Budiati et al., Profil Generasi Milenial Indonesia, 2018, www.freepik.com.
} 
milenial. ${ }^{35}$ Generasi produktif ini perlu mendengar dan percaya akan Injil agar mereka tidak terhilang dan akhirnya diselamatkan.

Fakta kondisi rohani seseorang yang tidak memercayai Injil, disebutkan oleh Firman Allah secara jelas. ${ }^{36}$ Fakta tersebut dapat diringkas sebagai berikut: ${ }^{37}$ Pertama, bahwa tanpa terkecuali, setiap manusia telah berdosa dan patut untuk dihukum (Roma $3: 23 ; 6: 23)$. Kedua, apapun usaha manusia untuk dapat lepas dari penghukuman Allah pasti akan berujung pada kegagalan. ${ }^{38}$ Akibat keberdosaannya, manusia pasti dihukuman oleh Allah meskipun dengan segala kebenarannya, karena pada dasarnya, tidak ada satupun dari mereka yang benar di hadapan Allah (Roma 3:11). Palmer menjelaskan bahwa kerusakan total pada setiap manusia telah menyebabkannya jahat dan cenderung menyeleweng dari hadapan Allah (Roma 3:12). ${ }^{39}$ Lalu bagaimanakah manusia dapat terlepas dari penghukuman Allah?

Rupanya Alkitab juga memberikan solusi agar manusia dapat terlepas dari penghukuman itu. Melalui Injil yang menyelamatkan, manusia dapat terlepas dari keadaan tersebut (Roma 1:16-17). Dan ini seharusnya menjadi jawaban bagi setiap manusia yang telah kehilangan pengharapan akibat dosa. ${ }^{40}$ Di dalam Injil terdapat pesan yang sangat penting untuk diberitakan agar manusia dapat diselamatkan, yaitu bahwa Allah berkarya melalui kematian Yesus Kristus di atas kayu salib untuk menggantikan hukuman mereka, dan setiap orang yang mau beriman kepada Yesus akan dilepaskan dari penghukuman serta memperoleh hidup yang kekal (Yoh. 3:16). Bahkan kebangkitan-Nya membuktikan kemenangannya atas kuasa dosa (I Kor. 15:17-20) ${ }^{41}$

Pesan penting di atas harus diberitakan kepada generasi milenial Indonesia melalui metode yang sesuai dengan konteks mereka. Generasi milenial yang sangat dipengaruhi dengan digital culture, perlu mendapatkan pesan Injil yang sesuai dengan konteks budaya mereka. Usaha ini sering disebut dengan kontekstualisasi. Kontekstualisasi adalah usaha untuk mendapatkan cara yang tepat dalam mengkomunikasikan berita Injil agar relevan dengan budaya masyarakat yang disapa oleh berita tersebut. Pewarta Injil perlu mempertimbangkan hal ini, agar Injil tetap relevan dengan generasi milenial.

Kedekatan generasi milenial dengan YouTube, dapat menjadi peluang bagi pewarta Injil untuk menggunakan varian media sosial ini sebagai medium Injil. Hal ini selaras dengan konteks kehidupan para milenial, yang mediavora (pelahap media), multi-

${ }^{35}$ Ibid.

${ }^{36}$ David Eko Setiawan, “Dampak Injil Bagi Transformasi Spiritual dan Sosial,” BIA': Jurnal Teologi dan Pendidikan Kristen Kontekstual 2, no. 1 (2019): 87.

${ }^{37}$ Stanley Heath, Penginjilan dan Pelayanan Pribadi (Surabaya: PN YAKIN, n.d.), 22.

38 Ibid., 37.

${ }^{39}$ Edwin Palmer, 5 Pokok Calvinisme (Jakarta: Lembaga Reformed Injili Indonesia, 1996), 8-14.

${ }^{40}$ Setiawan, “Dampak Injil Bagi Transformasi Spiritual dan Sosial," 86.

${ }^{41}$ Ibid., 87. 
tasking, Hiper-Koneksi, tolerant real time dan interaktif. Para milenial mengakui bahwa YouTube adalah varian media sosial yang cocok untuk online social interaction.

Pada 2-4 Juli 2020, peneliti melakukan survei terhadap warga gereja di Jawa Tengah dengan jumlah partisipan sebanyak 56 orang. Dalam survei ini ditemukan data bahwa 98,2 \% dari mereka aktif dalam mengakses YouTube dan 52,7 \% dari mereka adalah generasi milenial. ${ }^{42}$ Peneliti telah menyajikan data tersebut pada diagram berikut. Diagram 1.

Keaktifan Partisipan dalam Mengakses YouTube

Apakah anda pengguna Platform Youtube ?

56 jawaban

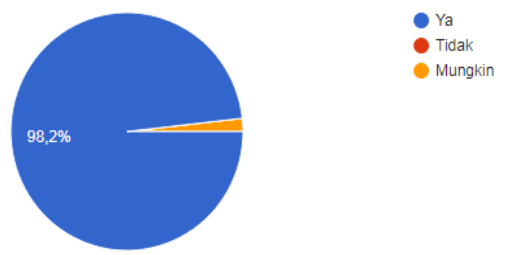

Selanjutnya, rata-rata usia partisipan yang terlibat dalam survei ini adalah 20- 55 tahun dengan komposisi sebagai berikut: Pertama, lahir pada tahun 1965-1979 sebanyak 5,4\%. Kedua, lahir pada tahun 1980-2000 sebanyak 51,8\%. Ketiga, lahir pada tahun 2000 ke atas sebanyak $28,6 \%$.

Diagram 2.

Komposisi Partisipan Menurut Tahun Kelahirannya

Berapakah tahun kelahiran anda?

56 jawaban

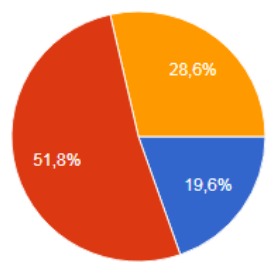

$1965-1979$

- $1980-2000$

2000-ke atas

Berdasarkan hasil survei terhadap 56 partisipan menunjukkan bahwa 80,4\% partisipan menyatakan bahwa YouTube merupakan platform media sosial yang atraktif, kreatif, interaktif, dan inspiratif.

${ }^{42}$ Metode Survei yang digunakan dalam penelitian ini menggunakan instrumen pertanyaan ditulis yang berjumlah 8 dan dibagikan menggunakan aplikasi Google Form kepada 56 partisipan. Sedangkan data yang terkumpul dianlaisis secara deskriptif untuk dapat memberikan gambaran yang jelas terhadap topik yang sedang dibahas. 


\section{Diagram 3.}

YouTube sebagai Platform media yang Atraktif, Kreatif dan Inspiratif

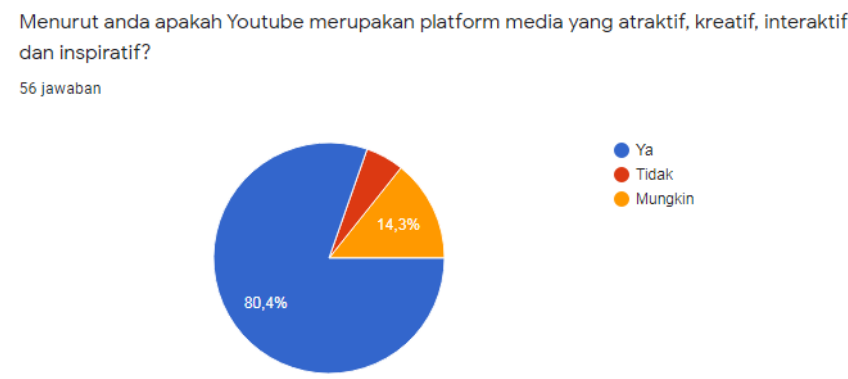

Lalu bagaimanakah tanggapan mereka sehubungan dengan YouTube sebagai medium pewartaan Injil? 89, 3 \% responden menyatakan setuju jika YouTube dijadikan medium pewartaan Injil.

\section{Diagram 4.}

YouTube dapat Menjadi Medium Pewartaan Injil

Apakah setuju jika platform Youtube menjadi medium (alat) bagi Pewartaan Injil ?
56 jawaban

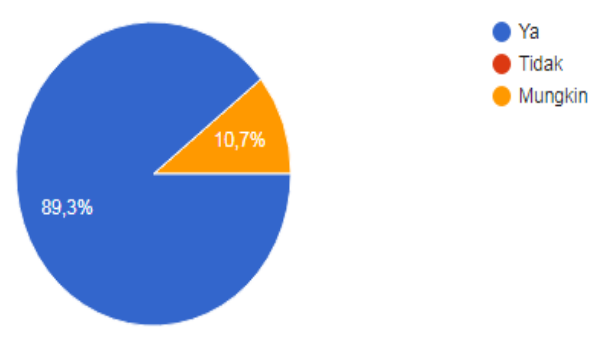

Selanjutnya, 71,4\% partisipan juga melihat bahwa YouTube merupakan medium yang efektif untuk memperkenalkan Injil kepada generasi Milenial. Hal tersebut tampak dalam diagram di bawah ini.

\section{Diagram 5.}

YouTube dapat Menjadi Medium yang Efektif untuk Memperkenalkan Injil kepada Generasi Milenial

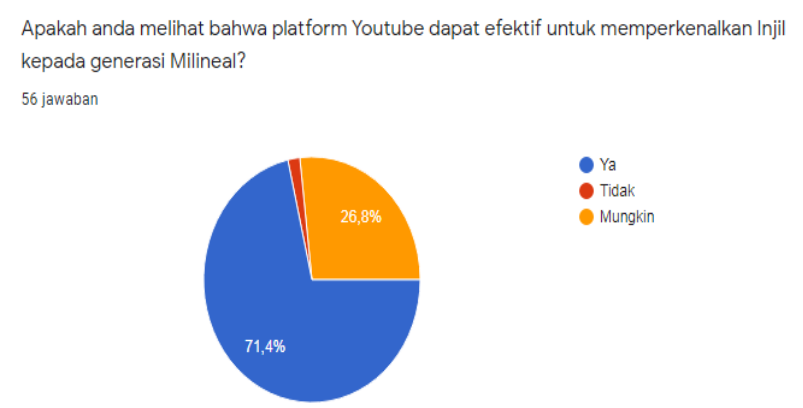

Dari survei yang dilakukan oleh peneliti ternyata didapatkan data bahwa 48,1\% warga gereja memandang bahwa telah banyak konten di YouTube yang bertemakan 
pewartaan Injil. Namun demikian perlu adanya peningkatan dari sisi mutu konten khususnya yang menjawab kebutuhan para milenial.

Diagram 6.

YouTube telah banyak Mengandung Konten Tentang Pewartaan Injil

Apakah menurut anda telah banyak konten di Youtube yang berisi tentang pewartaan Injil?

55 jawaban

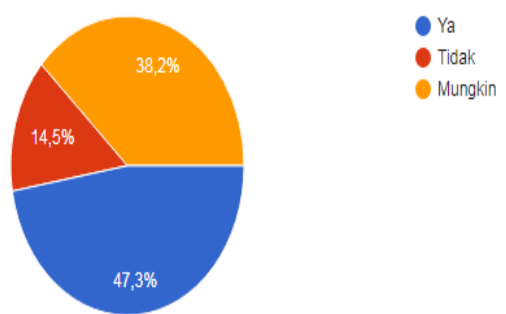

\section{Menjembatani Pesan Injil dan Generasi Milenial Melalui YouTube}

Pada dasarnya, isi pesan Injil yang berpusat pada Yesus Kristus dan karya-Nya tetap sama dan tidak berubah, namun demikian usaha untuk mengkomunikasikannya agar relevan pada satu konteks ke konteks yang lain tidak akan pernah selesai dan terus akan berubah seiring pengalaman serta kebudayaan manusia yang terikat oleh ruang dan waktu. ${ }^{43}$ Gereja harus terus bergumul agar berita Injil tetap relevan sepanjang zaman pada segala generasi.

Agar pesan Injil dapat dikomunikasikan secara tepat dan relevan bagi generasi milenial maka perlu dipahami adanya beberapa prinsip dasar dalam komunikasi yang efektif. Tomatala menjelaskan sebagai berikut: ${ }^{44}$ Pertama, tujuan komunikasi adalah mendorong sang penerima pesan untuk memahami makna pesan dan memotivasi pendengar untuk melakukan apa yang telah ia didengar. Kedua, kemampuan pendengar dalam memahami pesan dengan baik dan benar sangat bergantung pada kemampuan komunikator dalam menyampaikan pesan. Ketiga, komunikator dapat menggunakan lambang-lambang budaya yang sesuai dengan persepsi budaya pendengar sehingga dapat membangkitkan rangsangan terhadap pesan tersebut. Keempat, efektifitas sebuah komunikasi sangat ditentukan oleh pemahaman komunikator terhadap komunikan. Kelima, komunikator harus mempertimbangkan cara berkomunikasi yang lebih relevan dengan pemahaman pendengarnya agar dapat memberikan impact yang memadai. Keenam, interaksi antar pribadi memberikan pengaruh besar dalam proses komunikasi. Ketujuh, komunikator perlu memahami latar belakang kehidupan komunikan supaya

${ }^{43}$ Kleopas Sondegau, "Kristologi Dalam Konteks Kebudayaan Suku Migani Di Papua” 17, no. 1 (2017): 60-79.

${ }^{44}$ Y.Y Tomatala, Penginjilan Masa Kini (Penerbit Gandum Mas, 1997), 59-60. 
berita yang disampaikan terkait dengan kehidupan para pendengarnya. Kedelapan, pengaruh dan kredibilitas komunikator dalam lingkup budaya tertentu dapat memengaruhi efektifitas dalam penyampaian pesan. Kesembilan, dialog interaktif antara komunikator dengan komunikan akan memberikan peluang terjadinya komunikasi yang menarik.

Berdasarkan beberapa prinsip komunikasi di atas maka YouTube dapat menjadi medium yang efektif untuk menjembatani pewarta Injil dengan generasi milenial. Mengapa demikian? Peneliti mengamati bahwa platform YouTube memiliki kriteria yang relevan berdasarkan prinsip-prinsip tersebut. Pertama, YouTube mewakili budaya para milenial yaitu digital culture. Menggunakan YouTube berarti menggunakan lambang budaya yang sesuai dengan persepsi budaya para milenial. Dengan menggunakan lambang budaya yang relevan dengan mereka maka akan pesan yang disampaikan akan lebih mudah dipahami sehingga dapat menghasilkan impact yang memadai. Dengan memanfaatkan YouTube, pewarta Injil sebenarnya sedang berkomunikasi yang berorientasi kepada pendengar. Kedua, YouTube memberikan ruang interaksi antar pribadi. Dengan adanya kolom komentar terhadap konten video yang ditampilkan maka terjadi diskusi serta partisipasi aktif. Bahkan tidak sedikit melalui komentar-komentar tersebut dapat ditindaklanjuti secara pribadi. Ketiga, YouTube adalah platform media sosial yang sangat dekat dengan kehidupan para milenial. Pewarta Injil yang berkomunikasi melalui YouTube berarti sedang membangun jembatan yang efektif dengan kehidupan mereka.

\section{Pengelolaan Konten Berbasis Pewartaan Injil di YouTube Bagi Milenial Indonesia}

Mengingat begitu dekatnya generasi milenial Indonesia dengan YouTube, maka perlu adanya pengelolaan yang baik, benar dan menarik sehingga dapat dapat menjadi medium pewartaan Injil. Pengelolaan tersebut dapat diawali dari pemahaman yang tepat terhadap YouTube. Pada dasarnya YouTube merupakan varian media sosial yang berbasis platform video sharing, sehingga intinya dimulai dari pengelolaan terhadap video yang akan dibagikan sehingga dapat menarik dan tepat sasaran. Berdasarkan video tutorial persiapan membuat video YouTube yang menarik didapatkan beberapa langkah penting dalam mengelola video yang akan diunggah. Adapun langkah-langkahnya adalah sebagai berikut: ${ }^{45}$ Pertama, membuat topik khusus berkaitan dengan chanel video yang akan dibuat. Tujuan dari langkah ini adalah agar video-video yang akan dimuat di dalam chanel tersebut tidak bias dan lebih terfokus, sehingga pengakses akan mendapat informasi yang jelas dan dapat melanjutkannya melalui diskusi-diskusi yang sesuai dengan topik chanel. Berkaitan dengan pewartaan Injil, maka chanel yang akan dibuat sebaiknya memiliki

\footnotetext{
45 Den, "Persiapan Membuat Video Youtube Yang Menarik - Perhatikan Storynya!," Https://Www.Youtube.Com/, last modified 2018, diakses 20 Juli 2020, https:// www.youtube.com/watch?v=BN-aTwoGDSE.
} 
topik yang berhubungan dengan inti pesan Injil yaitu karya Allah melalui pribadi Kristus yang menyelamatkan manusia dari penghukuman dosa.

Kedua, mempersiapkan konten-konten yang menarik baik dari sisi jalan cerita, kreatifitas, tampilan dan lain sebagainya. Agar tercipta konten-konten yang menarik maka perlu dipersiapkan skrip atau storyline. Script adalah naskah yang akan menjadi panduan selama pengambilan dan editing video. Untuk mempersiapkan skrip membutuhkan waktu yang cukup lama karena harus menyesuaikan dengan topik dan konten video yang akan diunggah. Bahkan dalam membuat skrip perlu dipertimbangakan beberapa hal semisal; perkenalan singkat tentang creator dan isi dari channel juga ajakan kepada pengunjung baru untuk subscribe chanel tersebut, bahasa yang tidak bertele-tele, stimulan pada 15 detik pertama dalam video agar pengakses tertantang untuk menuntaskannya dan lain-lain. Beberapa petunjuk praktis tersebut berlaku pula pada pembuatan konten pewartaan Injil kepada milenialis. Agar pesan Injil dapat dinikmati dan dipahami dengan baik, maka perlu disusun lebih dahulu skrip yang singkat, padat dan tidak bertele-tele, namun langsung kepada topic masalah dan solusinya.

Ketiga, membuat video unik yang relevan dengan topik chanel. Chanel harus berisikan video-video yang bervariasi namun tetap unik dan relevan dengan topik channel agar para milenial tidak bosan atau bias dalam menangkap pesan dari chanel tersebut. Demikian juga konten video yang berbasis pewartaan Injil perlu dikemas seunik mungkin yang relevan dengan kehidupan para milenial Indonesia.

\section{Beberapa Contoh Channel di YouTube yang Relevan dengan Pewartaan Injil}

Dari survei yang dilakukan peneliti kepada warga gereja di Jawa Tengah menunjukkan bahwa 48,1\% dari para responden menyatakan bahwa telah ada konten-konten pewartaan Injil di YouTube. Artinya telah ada usaha dari gereja untuk memanfaatkan YouTube sebagai medium pewartaan Injil. Bahkan 70,9\% responden setuju bahwa YouTube dapat menjadi medium yang efektif untuk menjangkau generasi milenial, sebab 80\% responden menyatakan bahwa YouTube pada dasarnya merupakan varian media sosial yang atraktif, kreatif, interaktif dan inspiratif. Karakteristik YouTube tersebut relevan dengan sifat dan gaya hidup para milenial. Terdapat beberapa contoh Channel di Youtube yang relevan dengan pewartaan Injil, antara lain sebagai berikut: Christian Prince, Christopher Tapiheru, Raditya Oloan, Gilbert Lumoindong, dll.

\section{Kesimpulan}

Pesan Injil perlu diberitakan kepada semua manusia. Khususnya pada generasi milenial di Indonesia, pesan tersebut penting mengingat jumlah populasi generasi tersebut cukup besar. Mereka perlu mendengar Injil agar percaya dan diselamatkan. Melalui YouTube pesan Injil dikemas sedemikian rupa sehingga relevan dengan culture para milenial. 
YouTube sebagai medium pewartaan Injil bagi para milinialis rupanya signifikan. Hal ini didasarkan oleh relevansi karakteristik YouTube sebagai media sosial yang cocok bagi generasi milenial, yaitu media yang atraktif, kreatif, interaktif dan inspiratif.

\section{Referensi}

[BPS] Badan Pusat Statistik. Berita Resmi Statistik. Bps.Go.Id, 2020.

Budiati, Indah, Yusi Susianto, Widhiarso Ponco Adi, Sofaria Ayuni, Henri Asri Reagan, Putri Larasaty, Nia Setiyawati, Aprilia Ira Pratiwi, dan Valent Gigih Saputri. Profil Generasi Milenial Indonesia, 2018. www.freepik.com.

Cahyono, Anang Sugeng. "Pengaruh Media Sosial Terhadap Perubahan Sosial Masyarakat Di Indonesia." Jurnal Ilmu Sosial \& Ilmu Politik diterbitkan oleh Fakultas Ilmu Sosial \& Politik, Universitas Tulungagung 9, no. 1 (2016): 140-157. http://www.jurnalunita.org/index.php/publiciana/article/download/79/73.

Damayanti. Media Sosial, Identitas, Transformasi, dan Tantangannya. Malang, 2020.

Davis Stillman dan Jonah Stillman. Generasi Z. Jakarta: Gramedia, 2019.

Den. "Persiapan Membuat Video Youtube yang Menarik - Perhatikan Storynya!" Https://Www.Youtube.Com/. Last modified 2018. diakses 20 Juli, 2020. https://www.youtube.com/watch?v=BN-aTwoGDSE.

Dinar Apriyanto. Dinar Apriyanto. Bantul: Psikologi Corner, 2017.

Doni, Fahlepi Roma. “Perilaku Penggunaan Media Sosial Pada Kalangan Remaja” 3, no. 2 (2017): 15-23.

Faiza. "Mengenal Generasi Milenial." dalam Arus Metamorfosa Milenial, 1-183. Kendal: Penerbit Ernest, 2018.

Fatty Faiqah, Muh. Nadjib dan Andi Subhan Amir. "Youtube Sebagai Sarana Komunikasi Bagi Komunitas Makassarvidgram.” Jurnal Komunikasi KAREBA 5, no. 2 (2016): 259-272.

Heath, Stanley. Penginjilan Dan Pelayanan Pribadi. Surabaya: PN YAKIN, n.d.

Hutagalung, Stimson, dan Rolyana Ferinia. "Menjelajahi Spiritualitas Milenial : Apakah Membaca Alkitab , Berdoa , dan Menghormati Ibadah di Gereja Menurun ?" 2, no. 2 (2020): 97-111.

Kaplan, Andreas M., dan Michael Haenlein. "Users of the World, Unite! The Challenges and Opportunities of Social Media." Business Horizons 53, no. 1 (2010): 59-68.

Kartono, Kartini. Pengantar Metodologi Research Sosial. Bandung: Alumni Bandung, 1980.

Maksudi, Ike Atikah Ratnamulyani dan Beddy Iriawan. "Peran Media Sosial dalam Peningkatan Partisipasi Pemilih Pemula Dikalangan Pelajar di Kabupaten Bogor" 20, no. 2 (2018): 154-161.

Morrisan, M. A. Metode Penelitian Survei. Jakarta, 2012.

Nofitasari. "Pengaruh Media Sosial Terhadap Civic Disposition Generasi Milenial." Journal of Moral and Civic Education 2, no. 2 (2018): 64-76. 
Palmer, Edwin. 5 Pokok Calvinisme. Jakarta: Lembaga Reformed Injili Indonesia, 1996.

Panjaitan, Poppy. "Pengaruh Social Media Terhadap Produktivitas Kerja Generasi Millenial ( Studi Pada Karyawan PT . Angkasa Pura I Cabang Bandara Internasional Juanda )." Jurnal Administrasi Bisnis (JAB) 48, no. 1 (2017): 173-180.

Pasasa, Adrianus. "Pemanfaatan Media Internet Sebagai Media Pemberitaan Injil." Jurnal Simpson II (2015): 71-98.

Pratama, Hellen Chou. Cyber Smart Parenting: Kiat Sukses Menghadapi Dan Mengasuh Generasi Digital. Bandung, 2012.

Setiadi, Erik Fahron, Alia Azmi, and Junaidi Indrawadi. "Youtube Sebagai Sumber Belajar Generasi Milenial." Journal of Civic Education 2, no. 4 (2019): 313-323.

Setiawan, David Eko. "Dampak Injil Bagi Transformasi Spiritual Dan Sosial." BIA': Jurnal Teologi dan Pendidikan Kristen Kontekstual 2, no. 1 (2019): 83-93.

Sibarani, Apriani M. "Media Sosial Sebagai Konteks Pendidikan Kristiani Kontekstual Bagi Generasi Millennial." Jurnal Ilmiah Maksitek 5, no. 2 (2020): 13-18.

Sondegau, Kleopas. “Kristologi Dalam Konteks Kebudayaan Suku Migani Di Papua” 17, no. 1 (2017): 60-79.

Suyanto, Bagong. Metode Penelitian Sosial: Berbagai Alternatif Pendekatan. Jakarta, 2015.

Tari, Ezra. “Teologi Tongkonan: Berteologi Dalam Konteks Budaya Toraja” 2, no. 2 (2018): 93-102.

Tomatala, Y.Y. Penginjilan Masa Kini. Penerbit Gandum Mas, 1997.

We Are Social \& Hootsuite. "Digital Data Overview 2021: Indonesia." Global Digital Insights.

- - Indonesia Digital Report 2020. Global Digital Insights, 2020. https://datareportal.com/reports/digital-2020-global-digital-overview. 